\title{
Novel and Transient Populations of Corticotropin-Releasing Hormone-Expressing Neurons in Developing Hippocampus Suggest Unique Functional Roles: A Quantitative Spatiotemporal Analysis
}

\author{
Yuncai Chen, ${ }^{1}$ Roland A. Bender, ${ }^{1}$ Michael Frotscher, ${ }^{2}$ and Tallie Z. Baram ${ }^{1}$ \\ ${ }^{1}$ Departments of Anatomy/Neurobiology and Pediatrics, University of California at Irvine, Irvine, California 92697-4475, \\ and 2Institute of Anatomy, University of Freiburg, D-79104 Freiburg, Germany
}

Robust physiological actions of the neuropeptide corticotropinreleasing hormone $(\mathrm{CRH})$ on hippocampal pyramidal neurons have been demonstrated, which may contribute to synaptic efficacy and to learning and memory processes. These excitatory actions of the peptide, as well as the expression of the $\mathrm{CRH}$ receptor type that mediates them, are particularly prominent during early postnatal life, suggesting that endogenous $\mathrm{CRH}$ may contribute to processes involved in maturation of hippocampal circuitry. To further elucidate the function(s) of endogenous $\mathrm{CRH}$ in developing hippocampus, we used neurochemical and quantitative stereological methods to characterize in detail $\mathrm{CRH}$-expressing neuronal populations during postnatal hippocampal differentiation. These experiments revealed progressively increasing numbers of $\mathrm{CRH}$-expressing neurons in developing hippocampus that peaked on postnatal day 11-18 and then declined drastically to adult levels. These cells belonged to several discrete populations, distinguished by GAD67 mRNA expression, morphology, and distinct spatiotemporal distribution profiles. Importantly, a novel population of Cajal-Retzius-like $\mathrm{CRH}$-expressing neurons was characterized that exists only transiently in early postnatal hippocampus and is positioned to contribute to the establishment of hippocampal connectivity. These findings suggest novel, age-specific roles for $\mathrm{CRH}$ in regulating early developmental events in the hippocampal formation.

Key words: hippocampus; dentate gyrus; Cajal-Retzius cells; $G A D$; interneurons; neuropeptide; development; corticotropin releasing hormone; CRF
The neuropeptide corticotropin-releasing hormone $(\mathrm{CRH})$ functions as the primary regulator of the neuroendocrine responses to stress (Vale et al., 1981). Hypothalamic CRH is released within seconds of stress onset from terminals of peptidergic neurons to influence pituitary hormonal secretion (Rivier et al., 1983; Yi and Baram, 1994). It has been increasingly recognized, however, that the actions of $\mathrm{CRH}$ are not confined to the neuroendocrine, hypothalamic-pituitary-adrenal system. Studies of the distribution of $\mathrm{CRH}$ in both adult and developing $\mathrm{CNS}$ have revealed the presence of significant populations of $\mathrm{CRH}$-expressing neurons in discrete limbic regions, in particular the central nucleus of the amygdala (Swanson et al., 1983; Gray and Bingaman, 1996) and the hippocampus (Swanson et al., 1983; Merchenthaler, 1984; Sakanaka et al., 1987; Yan et al., 1998). In addition, CRH has been shown to act directly on central neurons (Aldenhoff et al., 1983; Valentino et al., 1983; Fox and Gruol, 1993; Curtis et al., 1995; Hollrigel et al., 1998), suggesting neuromodulatory roles for the peptide within the CNS.

Whereas evidence from a number of studies indicates that amygdalar CRH may function in its traditional role as a mediator of central stress responses (Swiergiel et al., 1993; Kalin et al., 1994; Hatalski et al., 1998; Merali et al., 1998), the role of hippocampal CRH has remained obscure. In adult rat hippocam-

Received Jan. 17, 2001; revised June 15, 2001; accepted June 27, 2001.

This work was supported in part by National Institutes of Health Grant NS 28912 (T.Z.B.) and the Deutsche Forschungsgemeinschaft (M.F.). We thank Drs. C. A. Haas and A. Tielsch for providing reelin cDNA and Drs. N. J. K. Tillakaratne and A. J. Tobin for transcription vectors containing GAD67 cDNA.

Correspondence should be addressed to Dr. Tallie Z. Baram, Departments of Anatomy/Neurobiology and Pediatrics, University of California at Irvine, Irvine, CA 92697-4475. E-mail: tallie@uci.edu.

Copyright (ㄷ) 2001 Society for Neuroscience $0270-6474 / 01 / 217171-11 \$ 15.00 / 0$ pus, $\mathrm{CRH}$ expression has generally been considered to be confined to inhibitory interneurons (Swanson et al., 1983; Merchenthaler, 1984; Smith et al., 1997; Yan et al., 1998). However, the physiological actions of $\mathrm{CRH}$ in hippocampus are excitatory (Aldenhoff et al., 1983; Smith and Dudek, 1994; Hollrigel et al., 1998). Thus, in the presence of depolarizing input, activation of $\mathrm{CRH}$-receptors enhances the excitability of a neuron and increases its firing rate (Aldenhoff et al., 1983; Hollrigel et al., 1998).

Several observations indicate an enhanced excitatory potency of $\mathrm{CRH}$ during development. Administration of picomolar amounts of the peptide into the cerebral ventricles of immature rats produces severe seizures that last for several hours (Baram et al., 1992; Baram and Hatalski, 1998), whereas much higher doses (200-fold) are required to elicit excitatory discharges in the adult (Ehlers et al., 1983). The basis for this age-dependent effect of CRH is not fully understood (for review, see Baram and Hatalski, 1998) but may relate to the abundance of target receptors. Binding studies, as well as in situ hybridization histochemistry, have shown that the receptor mediating the excitatory effects of $\mathrm{CRH}$ on neurons, $\mathrm{CRF}_{1}$ (Chalmers et al., 1995; Baram et al., 1997), is maximally expressed in immature hippocampus (400-600\% of adult levels) (Pihoker et al., 1992; Avishai-Eliner et al., 1996). This presence of high levels of $\mathrm{CRH}$ receptors during early postnatal development is intriguing and may also indicate specific roles for the peptide during hippocampal development.

To further elucidate the function(s) of $\mathrm{CRH}$ in developing hippocampus, we set out to delineate and characterize in detail CRH-expressing neuronal populations that are prominent in, or confined to, early postnatal development of the hippocampal formation. Using neurochemical and quantitative stereological 
methods, we established the increased abundance of $\mathrm{CRH}$ expressing neurons in developing hippocampus and discovered several distinct CRH-IR populations. Importantly, a population of Cajal-Retzius-like CRH-expressing neurons was characterized that exists only transiently in early postnatal hippocampus and is positioned to contribute to the establishment of hippocampal connectivity. These findings suggest novel, age-specific roles for $\mathrm{CRH}$ in regulating early developmental events in the hippocampal formation.

\section{MATERIALS AND METHODS}

Animals and tissue preparation. Immature Sprague Dawley-derived rats were born and maintained in a quiet, uncrowded, National Institutes of Health approved facility on a $12 \mathrm{hr}$ light/dark cycle, with access to lab chow and water ad libitum (Yi and Baram, 1994). On postnatal day 1 (P1), P5, P11, P18, or P80 (considering day of birth as day 0), brains were harvested under relatively stress-free conditions (Yan et al., 1998). Briefly, rats ( $n=4$ for each group) were left undisturbed for $24 \mathrm{hr}$ before experiments and were then deeply anesthetized with sodium pentobarbital $(100 \mathrm{mg} / \mathrm{kg}$, i.p.) within $45 \mathrm{sec}$ of entry into the animal facility. Anesthetized rats were removed to the laboratory and perfused using fresh $4 \%$ paraformaldehyde in $0.1 \mathrm{~m}$ sodium phosphate buffer (PB), $\mathrm{pH}$ $7.4\left(4^{\circ} \mathrm{C}\right)$. Brains were cryoprotected and stored as described previously (Chen et al., 2000) and then sectioned coronally into $20-\mu \mathrm{m}$-thick slices using a cryostat. To estimate the total number of CRH-IR neurons, consecutive sections throughout the entire hippocampus were harvested in $0.1 \mathrm{M}$ PB. For neuroanatomic orientation, 1 in 8 (P1, P5, and P11), 1 in 10 (P18), or 1 in 12 (P80) sections were stained with cresyl violet. Adjacent series were processed for immunocytochemistry (ICC) for $\mathrm{CRH}$ and calretinin, for in situ hybridization (ISH) for glutamic acid decarboxylase 67 (GAD67) mRNA and reelin mRNA, or for coanalysis of these neurochemical markers.

Immunocytochemistry. CRH-ICC was performed on free-floating sections using standard avidin-biotin complex methods as described previously (Yan et al., 1998; Chen et al., 2000). Briefly, after several washes with $0.01 \mathrm{M}$ PBS containing $0.3 \%$ Triton X-100 (PBS-T), pH 7.4, sections were treated for $30 \mathrm{~min}$ in $0.3 \% \mathrm{H}_{2} \mathrm{O}_{2}-\mathrm{PBS}$, followed by blockade of nonspecific sites with $2 \%$ normal goat serum in PBS for 30 min. After rinsing, sections were incubated for $36 \mathrm{hr}$ at $4^{\circ} \mathrm{C}$ with rabbit anti-CRH antiserum [1:40,000; a gift from Dr. W. W. Vale (Salk Institute, La Jolla, CA)] in PBS containing $1 \%$ bovine serum albumin and $2 \%$ normal goat serum and washed in PBS-T (three times for $5 \mathrm{~min}$ each). Sections were incubated in biotinylated goat anti-rabbit IgG (1:200; Vector Laboratories, Burlingame, CA) in PBS for $1 \mathrm{hr}$ at room temperature. After washing (three times for $5 \mathrm{~min}$ each), sections were incubated in the avidin-biotin-peroxidase complex solution (1:100; Vector Laboratories) for $2 \mathrm{hr}$ and rinsed (three times for $5 \mathrm{~min}$ each), and the reaction product was visualized by incubating the sections in $0.04 \% 3,3^{\prime}$-diaminobenzidine (DAB) containing $0.01 \% \mathrm{H}_{2} \mathrm{O}_{2}$.

In situ hybridization. Digoxigenin (DIG)-labeled antisense and sense probes were generated from a pBluescript transcription vector containing rat GAD67 cDNA (Erlander et al., 1991) and from mouse reelin cDNA that was synthesized using PCR (Haas et al., 2000). GAD67- and reelinISH was performed as described previously (Bender et al., 2000; Haas et al., 2000). Briefly, sections were washed with $2 \times \mathrm{SSC}(0.3 \mathrm{M} \mathrm{NaCl}$ and $0.03 \mathrm{~m} \mathrm{Na}$-citrate) for $30 \mathrm{~min}$ and then subjected to an additional $30 \mathrm{~min}$ incubation in a solution composed of $2 \times \mathrm{SSC}$-prehybridization solution (1:1). Prehybridization took place for $1 \mathrm{hr}$ at $55^{\circ} \mathrm{C}$ in a humid chamber. The prehybridization solution consisted of $50 \%$ formamide, $4 \times$ SSC buffer, $5 \times$ Denhardt's solution, $5 \%$ dextran sulfate, $100 \mu \mathrm{g} / \mathrm{ml}$ yeast tRNA, and $100 \mu \mathrm{g} / \mathrm{ml}$ salmon sperm DNA. For hybridization, DIGlabeled RNA probes were added, and sections were incubated at $55^{\circ} \mathrm{C}$ for at least $12 \mathrm{hr}$. For all steps, RNase-free solutions, sterile slides, and six-well plates were used. After hybridization, sections were washed in $2 \times \mathrm{SSC}$ at room temperature (two times for $15 \mathrm{~min}$ each), $50 \%$ formamide $-2 \times \mathrm{SSC}$ at $65^{\circ} \mathrm{C}$ for $60 \mathrm{~min}, 50 \%$ formamide $-0.1 \times \mathrm{SSC}$ at $65^{\circ} \mathrm{C}$ for $60 \mathrm{~min}$, and $0.1 \times \mathrm{SSC}$ at $65^{\circ} \mathrm{C}$ for $30 \mathrm{~min}$, and hybrid molecules were detected with an anti-DIG serum tagged with alkaline phosphatase according to the protocol of the manufacturer (Roche Products, Indianapolis, IN). Chromogens consisted of 4-nitro blue tetrazolium chloride and 5-bromo-4-chloro-3-indolyl phosphate (Roche Products). The specificity of the hybridization reaction was verified by substituting labeled sense probe for the antisense probe and by omitting either the antisense probe or alkaline phosphatase-conjugated antibody. No labeling was observed under these conditions.

Combined ISH-ICC. For double labeling, free-floating sections were first processed for ISH according to the protocol described above. Sections were rinsed and then processed for $\mathrm{CRH}$ - or calretinin-ICC, as above, with minor modifications. For visualization of $\mathrm{CRH}$ or calretinin immunoreaction, decreased concentrations of DAB $(0.02 \%)$ and $\mathrm{H}_{2} \mathrm{O}_{2}$ $(0.005 \%)$ were used. Sections were mounted on gelatin-coated slides, air-dried, and coverslipped with Permount. To evaluate the possibility of altered sensitivity or specificity attributable to combined ISH-ICC, sections processed only for ICC or ISH were compared with matched sections processed for double labeling. No differences in intensity, distribution, or number of labeled cells were observed.

Double-labeling ICC. Free-floating sections were processed for concurrent immunolabeling using a modification of the dual-chromogen procedure (Levey et al., 1986). Briefly, sections were first immunostained for $\mathrm{CRH}$ as described above, yielding a diffuse orange DAB reaction product. After $\mathrm{CRH}$ detection, sections were rinsed, incubated in 5\% normal horse serum for $30 \mathrm{~min}$, and then exposed to calretinin antiserum (1:20,000; Chemicon, Temecula, CA) for $36-48 \mathrm{hr}$ at $4^{\circ} \mathrm{C}$. Sections were incubated with biotinylated second antibody $(1 \mathrm{hr})$, followed by the avidin-biotin complex solution ( $2 \mathrm{hr}$ ), rinsed, transferred to $0.01 \mathrm{M} \mathrm{PB}$, $\mathrm{pH} 6.6$, for $30-45 \mathrm{~min}$, and then incubated in a chromogen solution ( $0.025 \%$ Na-nitroprusside and $0.01-0.02 \%$ benzidine dihydrochloride in buffer). The blue granular reaction product was visualized by incubating sections for 3-5 min in a solution containing $0.003 \% \mathrm{H}_{2} \mathrm{O}_{2}$. The reaction was stopped by rinsing $(0.01 \mathrm{M} \mathrm{PB}$ with $0.3 \%$ Triton $\mathrm{X}-100, \mathrm{pH}$ 6.6). The control measures described for the ISH-ICC procedure above to exclude altered sensitivity or specificity caused by the double-labeling procedure were performed.

Estimates of CRH-IR neurons. Total numbers of hippocampal CRH-IR neurons were estimated based on unbiased stereological principles (Sterio, 1984). For an unbiased determination of CRH-IR neurons, a systematic random series of sections (one in 8-12) throughout the entire anteroposterior extent of the hippocampal formation was selected, yielding 14-20 sections per animal. The rostral sampling boundary was the first section containing both CA3 and dentate gyrus (DG) (for early postnatal ages, see Paxinos et al., 1991, their Fig. 92; for older ages, see Paxinos and Watson, 1982, their Fig. 18). The caudal boundary consisted of sections no longer containing hippocampal subdivisions (Paxinos et al., 1991, their Fig. 111; or Paxinos and Watson, 1982, their Fig. 28). The major hippocampal subdivisions analyzed were CA1, CA3, and the dentate gyrus, defined according to Freund and Buzsáki (1996). Cell nuclei were counted using the "optical dissector" technique (Gundersen et al., 1988; West, 1999) relying on the leading edges of nuclei in each section. After inspection of CRH-IR neurons in each of the hippocampal subdivisions under $20 \times$ magnification, counting was performed under a $100 \times$ oil immersion objective (numerical aperture, 1.4). The relatively small numbers of CRH-IR cells permitted counting of all such neurons in all hippocampal subdivisions of each sampled section.

Colocalization analyses. Colocalization of CRH with GAD67 mRNA, reelin mRNA, or calretinin was determined in eight sections per animal (two animals per age group). Counting was performed under $60 \times$ magnification, distinguishing the perinuclear blue mRNA label from the homogenous, orange-brown cytoplasmic CRH immunostain.

5'-Bromodeoxyuridine protocol and cell fate analysis. Timed-pregnant females were injected intraperitoneally with two doses of 5'bromodeoxyuridine (BrdU) $(50 \mathrm{mg} / \mathrm{kg}$ body weight; Sigma, St. Louis, MO) on embryonic day 10 (E10), E11, E12, or E13 to encompass the time of generation of pioneer neurons in strata radiatum (sr) and lacunosum moleculare (Supèr et al., 1998). Offspring were perfused transcardially with $4 \%$ paraformaldehyde at P1, P5, or P11. Brains were harvested and cut as described above. For detection of BrdU-labeled nuclei, sections were first treated with the following DNA denaturation steps: $2 \mathrm{hr}$ incubation in $50 \%$ formamide $-2 \times \mathrm{SSC}$ at $65^{\circ} \mathrm{C}, 10 \mathrm{~min}$ rinse in $2 \times \mathrm{SSC}$, $30 \mathrm{~min}$ incubation in $2 \mathrm{~N} \mathrm{HCl}$ at $37^{\circ} \mathrm{C}$, and $10 \mathrm{~min}$ rinse in $0.1 \mathrm{M}$ sodium borate, $\mathrm{pH}$ 8.5. Sections were rinsed in PBS-T and incubated with monoclonal rat anti-BrdU (1:2000; 20-24 hr; Accurate Chemicals, Westbury, NY). After rinsing in PBS-T, sections were incubated with biotinylated goat anti-rat IgG $(1: 1000 ; 1 \mathrm{hr}$; Chemicon), followed by the avidin-biotin complex solution (1:100; $2 \mathrm{hr}$; Vector Laboratories). For BrdU single labeling, the reaction product was visualized using DAB as chromogen (yielding brown nuclei). For CRH-BrdU double labeling, sections were first immunostained with rabbit anti-CRH (yielding a 

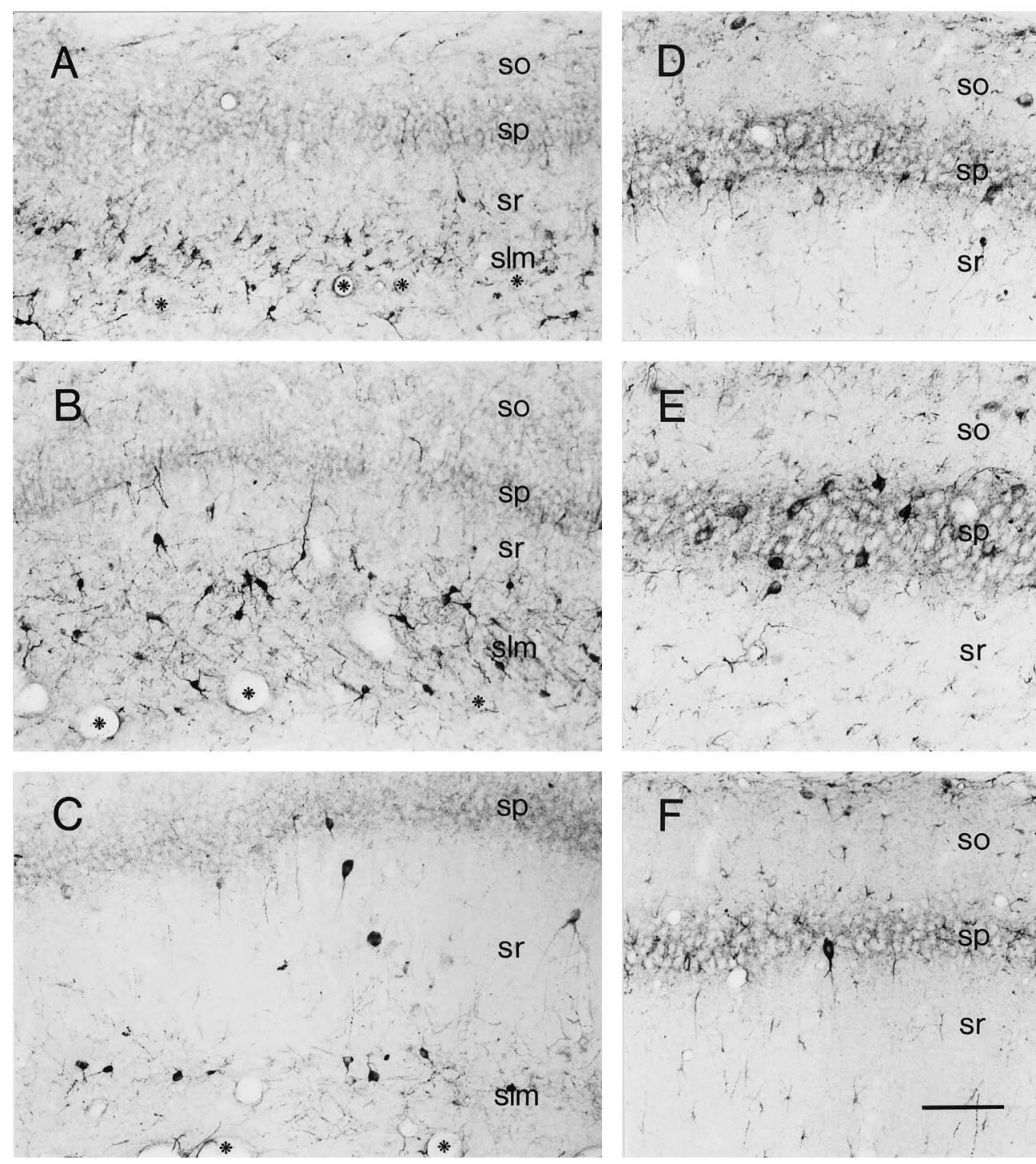

Figure 1. Distinct populations of CRH-IR neurons in hippocampal CA1 demonstrate a highly age-dependent spatiotemporal distribution pattern. $A$, As evident in a section from a $\mathrm{P} 1 \mathrm{rat}$, a dense population of $\mathrm{CRH}-$ expressing neurons inhabits slm, abutting the hippocampal fissure (demarcated by asterisks). Rare CRH-IR cells are found in sr and virtually none in sp or so. $B$, On P5, the morphologically heterogenous CRH-IR neuronal population in slm remains abundant, and more neurons are located also in sr. $C$, A remarkable decline in the CRH-IR neuronal population residing in $\mathrm{slm}$ is evident by P11. In contrast, CRH-expressing neurons occupy the pyramidal cell layer by this age. A more detailed view of this layer from a P11 rat is shown in $D$, demonstrating CRH-expressing somata, consistent with basket cells (these cells coexpress GAD67 mRNA; see Fig. $3 A, B$ ), as well as an axonal plexus outlining the $\mathrm{CRH}$ negative pyramidal cells. $E$, On P18, the population of CRH-IR interneurons residing in the sp is maximal. Their dense innervation of the pyramidal cells themselves is apparent. $F$, In adult CA1, few CRH-IR neurons are found in the pyramidal cell layer, consistent with the literature, and the numbers of $\mathrm{CRH}$-expressing neurons is low in other hippocampal layers as well (see Fig. 2 for quantitative analysis). Scale bar, $90 \mu \mathrm{m}$. brown DAB reaction product), followed by anti-BrdU as described above, using DAB-nickel to yield a black reaction product.

Initial evaluations indicated that $18-20 \%$ of $\mathrm{CRH}$-positive CajalRetzius cells were labeled with BrdU when animals received the BrdU injections at E12, consistent with numbers expected if the majority of these cells were born on this date. Thus, progeny of E12 injected rats were used for cell fate analysis. Every eighth section of the dorsal hippocampus (8-10 sections per rat, three rats per age) was selected. Cells containing BrdU-labeled nuclei and CRH-BrdU cells were counted in the outer molecular layer $(\mathrm{ml})$ of the dentate gyrus and in a two cell body wide zone of stratum lacunosum moleculare (slm) abutting the hippocampal fissure. Data are expressed as number of cells per section (BrdU) or per eight sections (see Fig. $7 F$, CRH-BrdU).

Statistical analysis. Results are presented as mean \pm SEM. The effect of age was determined using a one-way ANOVA, followed by either Newman-Keuls or Dunnett's multiple comparison post hoc tests. In all cases, significance levels were set at $p<0.05$.

\section{RESULTS}

\section{Spatiotemporal analysis of the distribution of $\mathrm{CRH}-\mathrm{IR}$ neurons in the developing hippocampus}

CRH-IR neurons were found in the hippocampal formation as early as P1 (Figs. $1 A, 2 A$ ). The total number of CRH-IR neurons in the hippocampal formation increased progressively during postnatal development, peaking at P18 (Figs. $2 A, 3 A, B, E, F, 4 B$ ), and declining thereafter to result in substantially fewer CRH-IR neurons in adult hippocampus (P80) (Figs. $1 F, 2 A, 4 C$ ). The spatiotemporal expression profile of $\mathrm{CRH}$ was highly heterogenous, so that individual subfields and layers of the hippocampal formation contributed differentially to the overall quantitative pattern of $\mathrm{CRH}$ expression (Figs. 1, 2B--D). In particular, the distribution of CRH-IR neurons during the earlier postnatal time points was striking. The two regions in developing hippocampus that correspond to the marginal zone in neocortex, CA1 slm and the $\mathrm{ml}$ of the DG, contained a prominent population of CRH-IR neurons that was concentrated along the hippocampal fissure (Figs. $1 A-C, 2 B, D, 4 D$ ). Indeed, on P1, the number of CRH-IR neurons located near the hippocampal fissure significantly exceeded that in any other hippocampal subfield (Figs. $1 A, 2 B-D$, $4 A$ ). This CRH-IR neuronal population was still quite robust on P5 (Figs. $1 B, 2 B-D$ ) but declined rapidly by P11 (Figs. $1 C, 2 B-D$, $4 E$ ). In hippocampi from P18 and older animals, relatively few CRH-IR cells $(981 \pm 157$ in the adult compared with $4568 \pm 302$ on $\mathrm{P} 1$, or $21.4 \%$ ) remained in these former marginal zones (Figs. $2 B-D, 4 F)$.

The populations of CRH-IR neurons in the principal cell layers [pyramidal and granule cell layer $(\mathrm{gl})$ ], as well as in strata oriens (so), sr, and the hilus demonstrated a diametrically opposite trend 
A
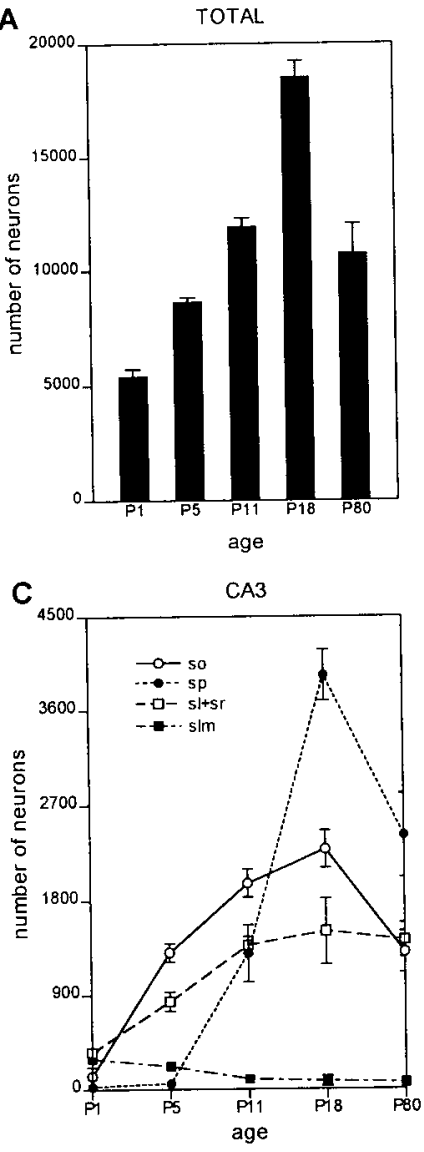

B

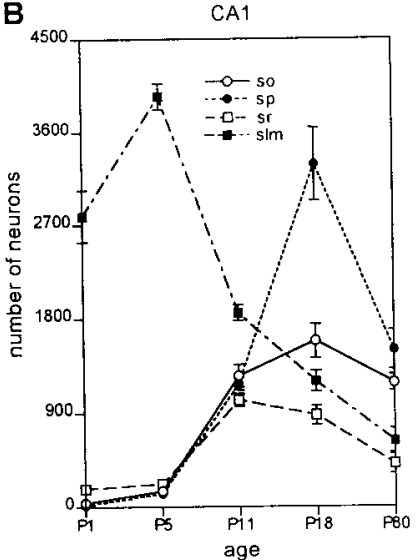

D

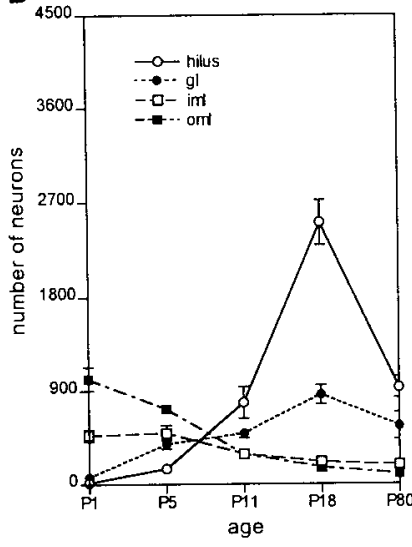

Figure 2. Quantitative analysis of total numbers and regional distribution of CRH-expressing neurons in the developing rat hippocampal formation. $A$, Age-specific estimates, based on stereological analysis (see Materials and Methods), of the total numbers of CRH-IR neurons demonstrate progressive increase from $\mathrm{P} 1$ to $\mathrm{P} 18$, with a subsequent decline to adult levels. ANOVA indicates a significant effect of age $(F=45.20 ; p<$ 0.0001). These overall values represent the sum of several distinct cell populations that occupy specific layers and regions of the developing hippocampus. $B$, In CA1, the number of CRH-expressing neurons located in the slm peaks on P5 and declines to $16 \%$ of P5 values by adulthood. Conversely, the numbers of CRH-expressing neurons in the sp on P18 is $>200$-fold higher than on $\mathrm{P} 1$ and $220 \%$ of adult values. $C, D$, The distinct spatio-developmental profiles of several CRH-IR neuronal populations is reflected also in $\mathrm{CA} 3(C)$ and the dentate gyrus $(D)$. Peak numbers of CRH-IR interneurons (see Fig. $3 A, B$ ) occupy the principal cell layers on $\mathrm{P} 18$; in contrast, the population of CRH-expressing (non-GABAergic) cells near the hippocampal fissure [slm and outer molecular layer (oml)] decline precipitously with age. iml, Inner molecular layer. Values are presented as mean \pm SEM for four rats per age group.

compared with that of CRH-IR neuronal populations residing near the hippocampal fissure. $\mathrm{CRH}$-expressing neurons were virtually absent in stratum pyramidale (sp) and gl on P1 (Figs. $1 A$, $2 B-D, 4 A, D)$ and were rare on $\mathrm{P} 5$ (Figs. $1 B, 2 B-D)$. Their numbers increased progressively with age until P18 (Figs. $1 E$, $2 B-D, 3 A, B, 4 B)$ and declined thereafter. A similar trend was found for CRH-IR neuronal populations located in so, sr, and in the hilus (Fig. $2 B-D$ ). Thus, the total number of CRH-IR neurons was maximal in the immature (P11 and P18) hippocampal formation, peaking at $\sim 200 \%$ of adult values. In addition, the overall increase in the total number of CRH-IR neurons in the hippocampal formation during the first 3 postnatal weeks was attributable to an absolute and dramatic rise in the number of CRH-IR neurons in the principal and polymorph layers (Fig. $2 B, C$, so, sr,

and hilus), which overrode the drastic loss of CRH-IR neurons located in the slm and $\mathrm{ml}$.

\section{Neurochemical characterization reveals a transient, non-GABAergic population of CRH-IR neurons in the developing hippocampus}

To characterize the functional properties of CRH-IR neurons in the developing hippocampal formation, we combined CRH-ICC with ISH for GAD67 mRNA, a marker for GABAergic neurons (Houser and Esclapez, 1994). This analysis revealed that CRH-IR neurons present in the early postnatal hippocampus represented at least two clearly distinguishable populations; the large majority of CRH-IR neurons in the principal cell layers, as well as in so, sr, and hilus, coexpressed GAD67 mRNA, suggesting that they functioned as GABAergic local circuit neurons (Figs. 3, 5A,B). In contrast, CRH-IR neurons located near the hippocampal fissure rarely coexpressed GAD67 mRNA (Figs. 5, $6 B, H)$. Quantitative analysis of CRH-IR neurons colocalizing GAD67 mRNA at different ages (Fig. 5) better illustrated the fate of this population during development compared with that of non-GABAergic CRH-IR cells. Thus, on P5, the proportion of total hippocampal CRH-IR neurons coexpressing GAD67 mRNA was only $43 \%$ as a result of the large contribution of GAD67 mRNA-negative CRH-IR neurons in slm and ml. By P11, however, 75\% of all CRH-IR neurons coexpressed GAD67 mRNA (Fig. 5), indicating a doubling of GABAergic CRH-IR populations compared with $\mathrm{P} 5$. Because the total number of CRH-IR neurons increased only by $37 \%$ (Fig. $2 A$ ), this proportional increase of GABAergic CRH-IR neurons must have resulted from a sum of two independent processes: first, a progressive increase in the numbers of GAD67 mRNA-CRH colocalizing neurons in principal and polymorph cell layers; second, a decline of the GAD67 mRNA-negative-CRH-IR population in slm and $\mathrm{ml}$.

\section{A transient CRH-IR neuronal population near the hippocampal fissure possesses the neuroanatomical features of Cajal-Retzius cells}

In addition to their patterns of GAD67 expression, hippocampal $\mathrm{CRH}$-expressing neurons could be characterized as discrete populations based also on morphological, neurochemical, and localization criteria. Thus, CRH-IR neurons in slm and $\mathrm{ml}$ of the P1 and $\mathrm{P} 5$ rat belonged to two morphologically distinct populations. The first population consisted of small $(8-12 \mu \mathrm{m})$ multipolar neurons (Figs. $1 A, B, 6 G, H$ ), with varied orientation. These neurons, primarily GAD67 mRNA negative, were mainly observed in slm and in the inner $\mathrm{ml}$ of DG, usually at some distance from the hippocampal fissure. The second population consisted of neurons with a typical morphology described for rodent Cajal-Retzius cells (Derer and Derer, 1990) (Fig. 6A-D): large bipolar neurons, with one prominent dendrite oriented horizontally to the pial surface and fine appendages descending from the dendrite and soma toward the hippocampal fissure (and pia). This population was located close to the hippocampal fissure in slm and in the outer $\mathrm{ml}$ of DG and was virtually always devoid of GAD67 mRNA expression (Fig. $6 B$ ). Both populations were robust on P1 and $\mathrm{P} 5$ but declined drastically by $\mathrm{P} 11$ and later ages (Figs. $1 A-C$, $2 B-D, 5)$.

\section{Transient Cajal-Retzius-like CRH-IR neurons near the hippocampal fissure demonstrate a unique neurochemical profile}

To better characterize the neurochemical identity of these transient CRH-IR neurons, and guided by their morphology, we 

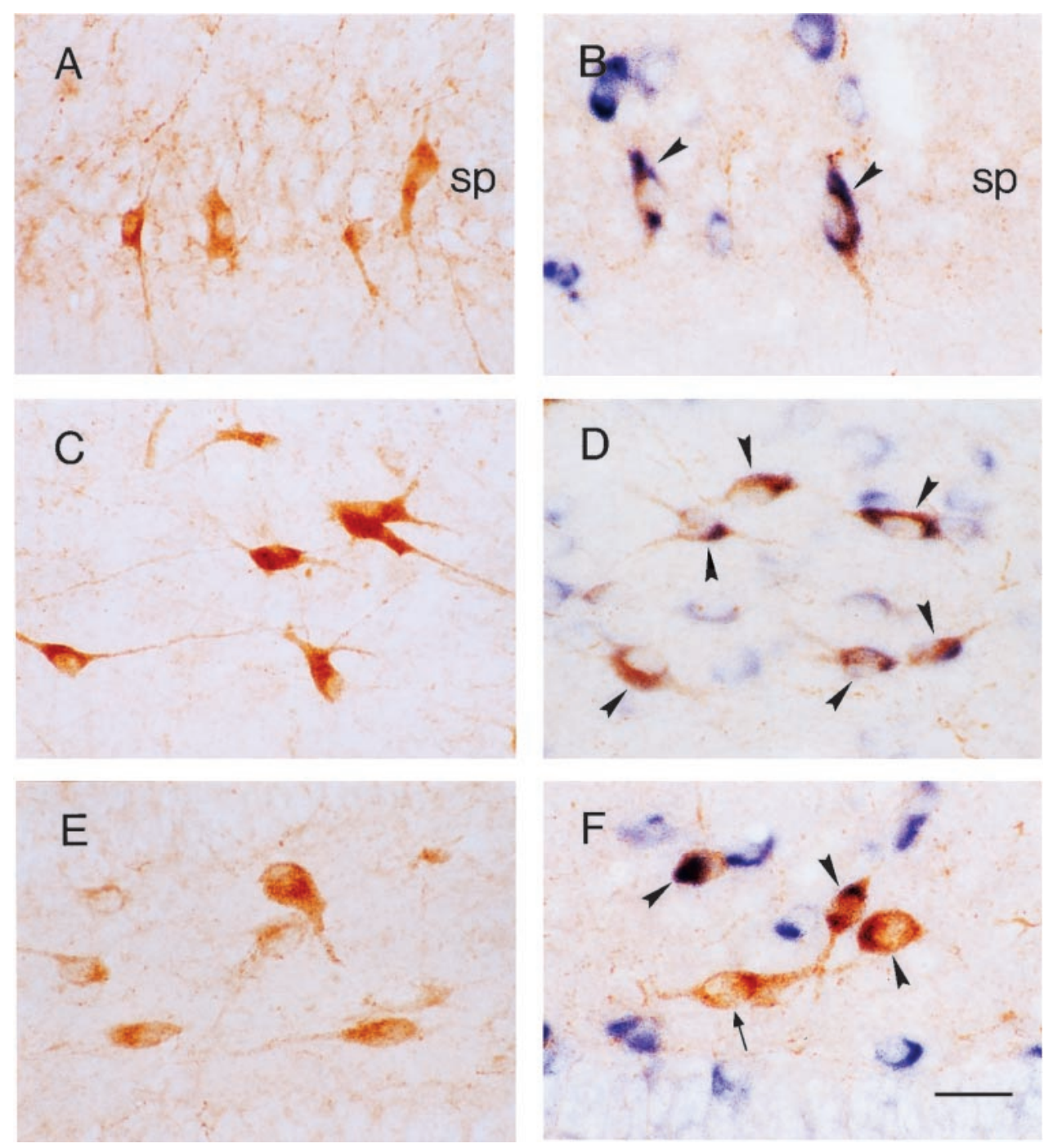

Figure 3. The majority of CRH-expressing neuronal populations in the principal hippocampal cell layers coexpress GAD67 mRNA, indicating their function as interneurons. $A, C$, and $E$ are sections labeled for CRH-IR; $B, D$, and $F$, demonstrate CRH-IR (orange) and GAD67 mRNA (blue). $A$ and $B$ demonstrate that, in the sp of the P18 rat, CRH-IR neurons are abundant, and virtually all coexpress GAD67 mRNA (arrowheads). $C, D$, In stratum oriens of the P5 rat, most CRH-IR neurons are GABAergic (arrowheads). $E, F$, In the dentate gyrus hilus of the P18 rat, a mixed population of CRH-IR neurons comprises both GABAergic (arrowheads) and GAD67-negative (arrow) cells. Also seen are numerous GABAergic interneurons bordering the granule cell layer that do not express CRH. Scale bar, $25 \mu \mathrm{m}$. determined whether they coexpressed neuronal markers for Cajal-Retzius cells. The extracellular matrix protein reelin has been proposed recently as a typical product of these cells (D’Arcangelo et al., 1995; Hirotsune et al., 1995; Ogawa et al., 1995). In situ hybridization histochemistry revealed that reelin mRNA-expressing neurons were abundant in the developing hippocampus (P5 and P11), both adjacent to the hippocampal fissure as well as in other hippocampal regions. These results, in concordance to other recent studies (Alcántara et al., 1998; Haas et al., 2000), indicate that reelin is not exclusively produced and secreted by Cajal-Retzius cells. Importantly, although Cajal-Retziuslike cells expressing reelin were intermingled with those expressing $\mathrm{CRH}$ near the hippocampal fissure, no coexpression of these two molecules by a single neuron was demonstrated (Fig. 6D).

As a second neuronal marker for Cajal-Retzius cells, we studied colocalization of $\mathrm{CRH}$ in these neurons with the calcium binding protein calretinin. Calretinin has been shown to be a specific neuronal marker for Cajal-Retzius cells in mice (Del Río et al., 1995) and is expressed by a subpopulation of Cajal-Retzius cells in rat hippocampus, where it also labels other neuronal populations (Jiang and Swann, 1997). However, whereas colocalization of calretinin and CRH was occasionally observed in multipolar neurons localized to the inner ml (data not shown), it was never observed in CRH-IR Cajal-Retzius cell-like neurons in the outer ml (Fig. 6C). It should be noted that coexpression of calretinin and reelin mRNA was observed frequently in neurons with Cajal-Retzius-like morphology near the hippocampal fissure (Fig. 6E,F), consistent with their neurochemical identity and validating the methodology used for double labeling of the cells we identified as Cajal-Retzius-like. Together, these findings indicate that the transient population of CRH-IR neurons with CajalRetzius cell-like morphology in the marginal zones (slm and $\mathrm{ml}$ ) of the early postnatal hippocampal formation constitutes a distinct subclass of Cajal-Retzius cells with unique neurochemical and consequent functional properties.

\section{Disappearance of transient CRH-IR Cajal-Retzius cells is attributable to their death rather than to phenotype change}

Several possible mechanisms may account for the disappearance of the CRH-expressing Cajal-Retzius cells. First, these neurons may change their phenotype and cease expressing detectable amounts of CRH. Alternatively, these neurons may die, as shown for other subpopulations of Cajal-Retzius cells (Del Río et al., 1995). To distinguish between these two fates, we performed a birth-dating study, using BrdU injection on E10-E13, days overlapping birth of hippocampal Cajal-Retzius cells in mouse (Supèr et al., 1998) and before the birth of most GABAergic neurons in 
Figure 4. Populations of CRH-IR neurons in hippocampal CA3 $(A-C)$ and dentate gyrus $(D-F)$ demonstrate a highly age-dependent spatiotemporal distribution pattern. $A-C$ are sections derived from animals on $\mathrm{P} 1, \mathrm{P} 18$, and $\mathrm{P} 80$, respectively. $A$, On $\mathrm{P} 1$, most CRH-IR neurons congregate near the hippocampal fissure and rarely occupy the sp. $B$, Numerous CRH-IR neurons are located in sp on P18. $C$, By $\mathrm{P} 80$, the pyramidal cell layer is depleted of CRH-IR neurons. $D-F$, A remarkable "migration" of CRH-IR neurons is evident within the dentate gyrus. $D$, On $\mathrm{P} 1$, most are concentrated along the hippocampal fissure (asterisks) in the molecular layers. $E$, By P11, few CRH-IR neurons are observed in the outer $(\mathrm{oml})$ and inner $(\mathrm{iml})$ molecular layers; instead, these cells reside in the $\mathrm{gl}$ and hilus. $F$, By $\mathrm{P} 18$, the majority of $\mathrm{CRH}$-expressing neurons occupy the hilus. Scale bars: $A-C, 150$ $\mu \mathrm{m} ; D-F, 160 \mu \mathrm{m}$.
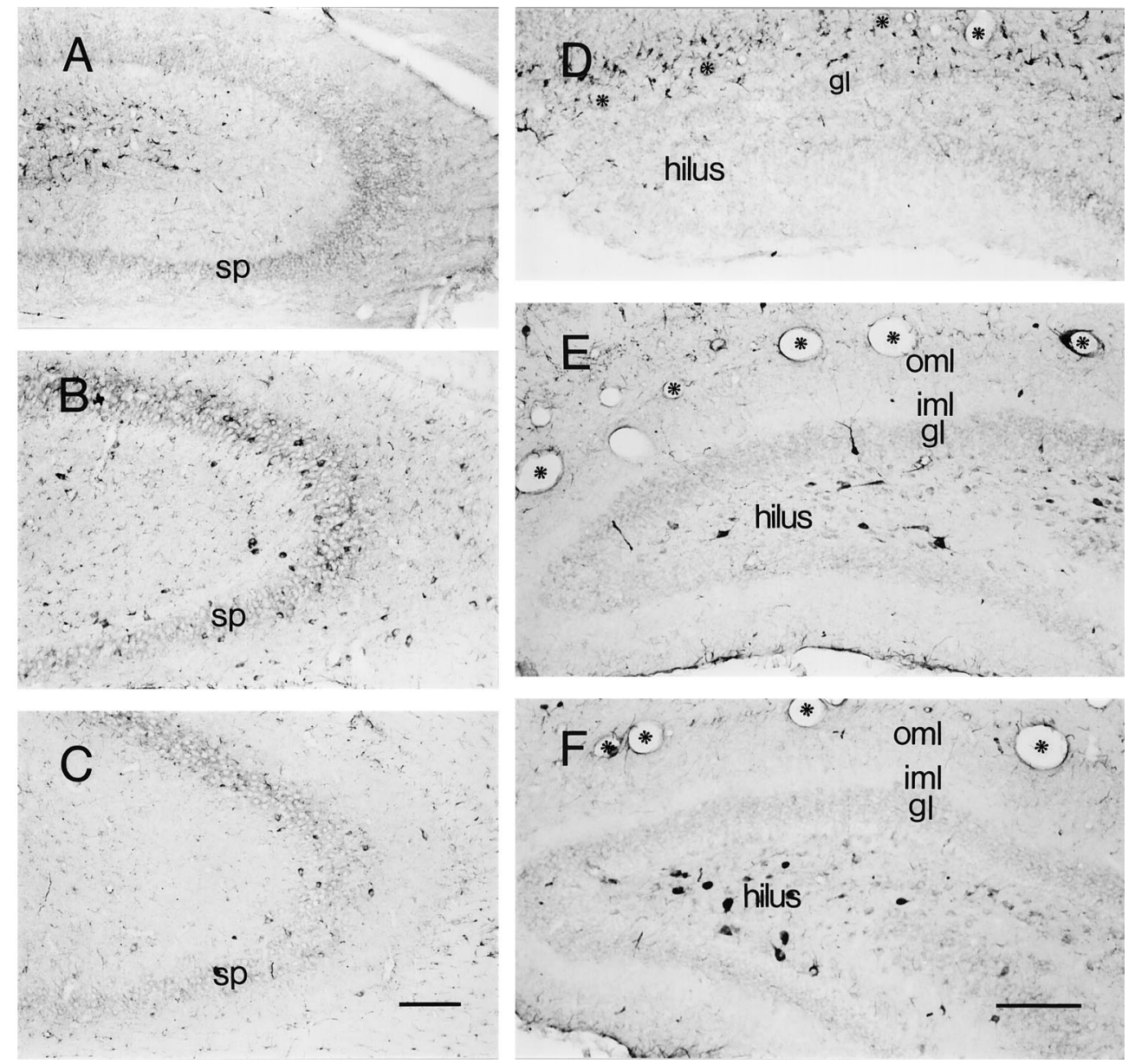

the rat (E14) (Amaral and Kurz, 1985; Dupuy and Houser, 1997). In animals injected on E12, 18-20\% of CRH-expressing cells with Cajal-Retzius cell morphology were also BrdU labeled. Because BrdU is available only for a limited time (Takahashi et al., 1992), this high proportion of BrdU labeling in CRH-positive neurons indicates that the injection occurred during the peak generation time of this neuronal population, which also concurs with the peak generation of Cajal-Retzius cells in general (Supèr et al., 1998). Numbers of BrdU-CRH-labeled cells were analyzed on P1, $\mathrm{P} 5$, and $\mathrm{P} 11$ and were compared with those labeled with BrdU alone. As evident from Figure $7 A$, many BrdU-labeled cells resided near the hippocampal fissure in the $\mathrm{P} 1$ rat. Their numbers decreased progressively by $\mathrm{P} 5$ and P11 (Fig. 7B,C). $\mathrm{CRH}-$ expressing, BrdU-labeled cells were also abundant in P1 (Fig. 7D), decreased by P5 (Fig. 7E), and were rarely observed by P11. Importantly, as shown in Figure $7 F$ (left) CRH-BrdU doublelabeled neurons disappeared from the hippocampal fissure at a rate similar to the disappearance rate of the population labeled with BrdU alone. The latter population, representing Cajal-Retzius cells, was found to undergo cell death (Del Río et al., 1995). It should be noted that the ratio of cells labeled for both $\mathrm{CRH}$ and BrdU to cells labeled with $\mathrm{CRH}$ alone (CRH-BrdU/CRH) remained quite constant (Fig. $7 F$, right), indicating that the doublelabeled cells are representative of the total CRH-expressing CajalRetzius population. In addition, hippocampal growth that occurred between P1 and P11 (on P5, 110\% of P1; on P11, 140\% of P1) was insufficient to account for the drastic reduction in the numbers of BrdU (and BrdU-CRH) -labeled cells.

\section{DISCUSSION}

The major results of this study are as follows. (1) CRH-IR neurons are significantly (twofold) more abundant in the immature compared with the adult rat hippocampus. (2) Based on anatomical and neurochemical criteria, a minimum of two populations of CRH-expressing neurons can be clearly distinguished in the developing hippocampus: a subclass of GABAergic (GAD67 mRNA-expressing) interneurons and an apparently transient population of non-GABAergic neurons concentrated near the hippocampal fissure. (3) A significant proportion of the CRH-IR non-GABAergic neurons possess the characteristic morphology of hippocampal Cajal-Retzius cells, and, like them, are born early in development and most die by the end of the second postnatal week. However, these cells express a unique neurochemical profile, suggesting distinct functional role(s). Together, these findings suggest that $\mathrm{CRH}$ may be involved in age-specific processes that contribute to postnatal hippocampal maturation.

\section{Abundance of $\mathrm{CRH}-\mathrm{IR}$ neurons and its potential relationship to the enhanced excitability of the developing hippocampus}

Excitability in the immature hippocampus circuit is generally considered to be enhanced compared with that of the adult, and several mechanisms have been suggested to account for this phenomenon (Swann, 1995; Ben-Ari et al., 1997; Holmes, 1997; Baram and Hatalski, 1998). The results of this study suggest that $\mathrm{CRH}$, released from abundant CRH-IR hippocampal neurons, 
A

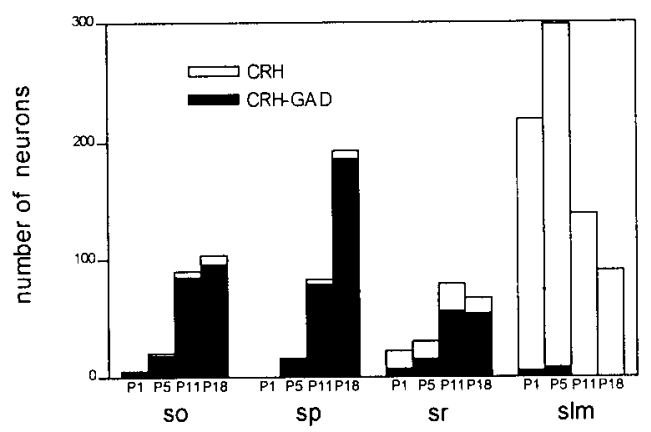

B

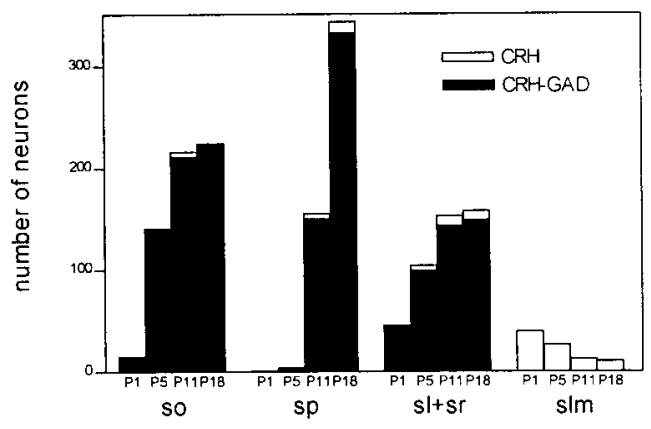

C

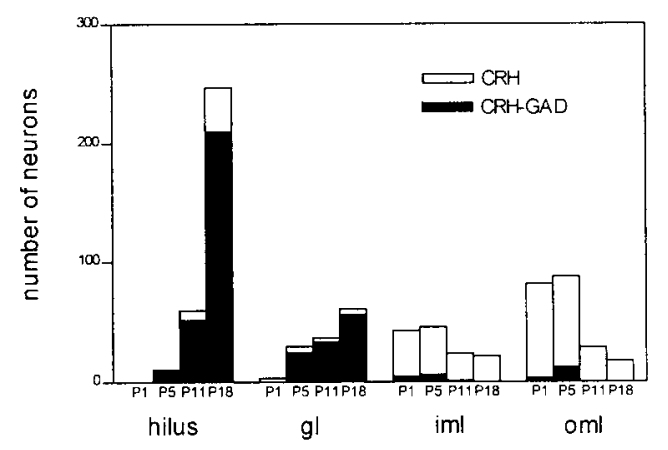

Figure 5. Quantitative analysis of GAD67 mRNA expression defines separate hippocampal CRH-expressing neuronal populations, with distinct spatial and age-dependent distribution profiles. Plotting GABAergic $\mathrm{CRH}$-immunoreactive neurons as a proportion of total peptideexpressing cells reveals that the former provide the major contribution to the striking increase of CRH-expressing cells in the principal cell layers between P1 and P18. In contrast, the transient populations in the hippocampal marginal zones [slm and outer molecular layer $(\mathrm{oml})]$ are non-GABAergic. Mixed populations reside in the polymorphic layers, sr, and the inner molecular layer $(\mathrm{iml})$. Quantitative data were derived from eight sections per rat (see Materials and Methods) and two animals per age group.

could contribute disproportionately to excitability in immature versus adult hippocampus (Baram and Hatalski, 1998).

An endogenous population of CRH-expressing neurons in the hippocampus has first been described in adult rat (Swanson et al., 1983; Merchenthaler, 1984; Sakanaka et al., 1987) and was recently also identified in immature rat (P10-P13) (Yan et al., 1998). Colocalization studies demonstrated that the large majority of these CRH-IR neurons were GABAergic interneurons, primarily basket or chandelier cells (Yan et al., 1998). These interneurons, synapsing on somata or axon initial segments of pyramidal neurons, typically play a key inhibitory role, modulating the output of the pyramidal cells (Soltesz et al., 1995). How- ever, the physiologic actions of CRH in hippocampus are excitatory (Aldenhoff et al., 1983; Hollrigel et al., 1998): in hippocampal slices, the peptide significantly increases firing rates of hippocampal pyramidal cells in the presence of an excitatory stimulus, essentially "amplifying" this input. In the absence of depolarizing input, CRH has little effect on the excitability of the network. Thus, although in some brain regions CRH may act directly as an excitatory neurotransmitter (Ehlers et al., 1983; Rainnie et al., 1992; Weiss et al., 1993; Curtis et al., 1995), in hippocampus its function may best be described as that of an excitatory neuromodulator. Therefore, release of the peptide from the relatively large numbers of CRH-IR interneurons in principal cell layers should contribute significantly to excitability of immature hippocampus.

This enhancement of glutamatergic synaptic transmission by CRH may contribute to physiological hippocampal processes of learning and memory (Lee et al., 1992, 1996; Baram and Hatalski, 1998) or stress responses (Hatalski et al., 2000). However, if released in excess, CRH may lead to pathological overexcitation of the immature hippocampus, as evident from the induction of prolonged seizures (involving hippocampus) by picomolar doses of $\mathrm{CRH}$ administered into the cerebral ventricles of immature rats (Baram et al., 1992; Baram and Hatalski, 1998). This may be attributable to the fact that, in addition to abundant CRH-IR neurons, expression levels of the CRH-receptor $\mathrm{CRF}_{1}$ [the receptor mediating excitatory actions of the peptide (Chalmers et al., 1995; Baram et al., 1997)] are fourfold to sixfold higher in immature compared with mature hippocampus (Pihoker et al., 1992; Avishai-Eliner et al., 1996). Thus, the present study demonstrates that the spatiotemporal profile of neurons providing an endogenous ligand for $\mathrm{CRH}$ receptors in hippocampus parallels the expression profile of receptor mRNA. Interestingly, during the second and third postnatal weeks, both endogenous ligand and the $\mathrm{CRF}_{1}$ receptor are particularly abundant in the CA3 pyramidal layer (Avishai-Eliner et al., 1996) (Figs. 2C, 4B, 5B). CA3 pyramidal neurons have been shown to be particularly excitable at that age (Swann, 1995), at least partially because of dense recurrent innervation by axonal branches that are later pruned (Gomez-Di Cesare et al., 1997). Activation of $\mathrm{CRF}_{1}$ receptor on the somata of these CA3 pyramidal cells (Chen et al., 2000) by CRH that is released from interneurons, thus provides a molecular machinery that may contribute to heightened excitability and seizure propagation during this developmental epoch. These effects of CRH may be important in certain age-specific developmental seizure disorders in the human (for review, see Baram and Hatalski, 1998).

\section{Potential developmental roles of GABAergic CRH-IR neurons in hippocampus}

The decline of the GABAergic CRH-IR population after the third postnatal week raises the question of the role that $\mathrm{CRH}$ might play during hippocampal maturation. Interestingly, similar expression profiles have also been reported for other neuropeptides; levels of somatostatin, cholecystokinin, neuropeptide Y, and cortistatin reach a peak in the second and third postnatal weeks and then decrease to adult values (Cho et al., 1983; Allen et al., 1984; Naus et al., 1988; de Lecea et al., 1997). The second and third postnatal weeks are a period of major maturational transitions in the hippocampal formation. For example, during the first postnatal week, hippocampal neuronal activity is mediated primarily by the depolarizing actions of GABA. GABAergic neurotransmission is then transformed into hyperpolarizing ef- 

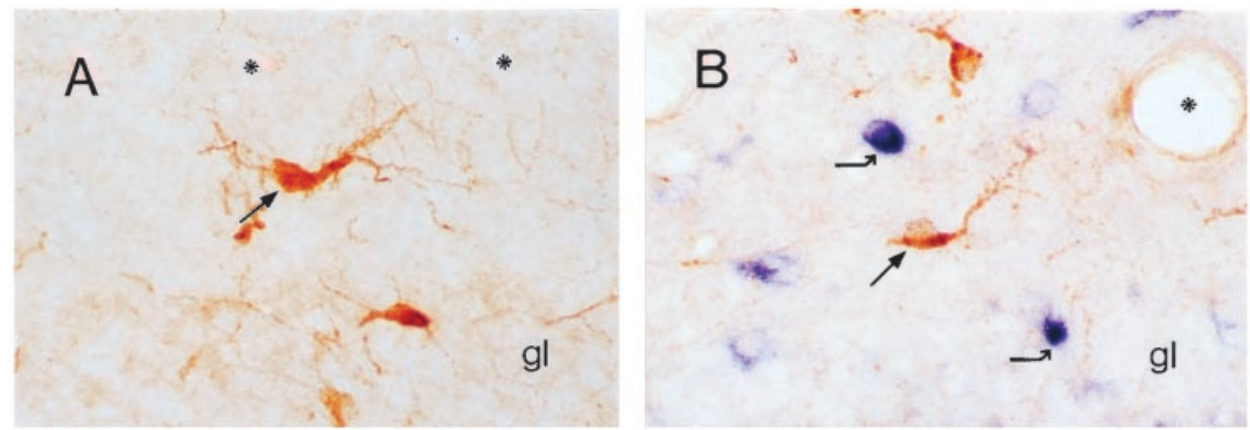

Figure 6. CRH-expressing Cajal-Retziuslike neurons demonstrate unique neurochemical characteristics. $A, \mathrm{CRH}$-immunoreactive neurons in the outer molecular layer of the dentate gyrus of the P5 rat (arrow) are aligned along the hippocampal fissure (asterisks) and possess a prominent thick dendrite with branches descending to the pial surface, typical of Cajal-Retzius cells. $B$, These CajalRetzius cell-like CRH-IR neurons (straight arrow) do not coexpress GAD67 mRNA (curved arrows). C, D, CRH-IR CajalRetzius-like neurons (arrows) do not coexpress neurochemical markers ascribed to subpopulations of rat Cajal-Retzius cells: calretinin $(C)$, shown as granular black deposits (curved arrows) or reelin mRNA ( $D$, curved arrows). $E, F$, In contrast, neurons colocalizing calretinin and reelin mRNA (arrowheads) are frequently observed near the hippocampal fissure. $G, H, \mathrm{CRH}-$ expressing neurons in the inner molecular layer of the dentate gyrus are morphologically distinct from the Cajal-Retzius-like population abutting the hippocampal fissure but demonstrate similar neurochemical characteristics and do not coexpress GAD67 mRNA (blue, curved arrows). Scale bar, $25 \mu \mathrm{m}$.
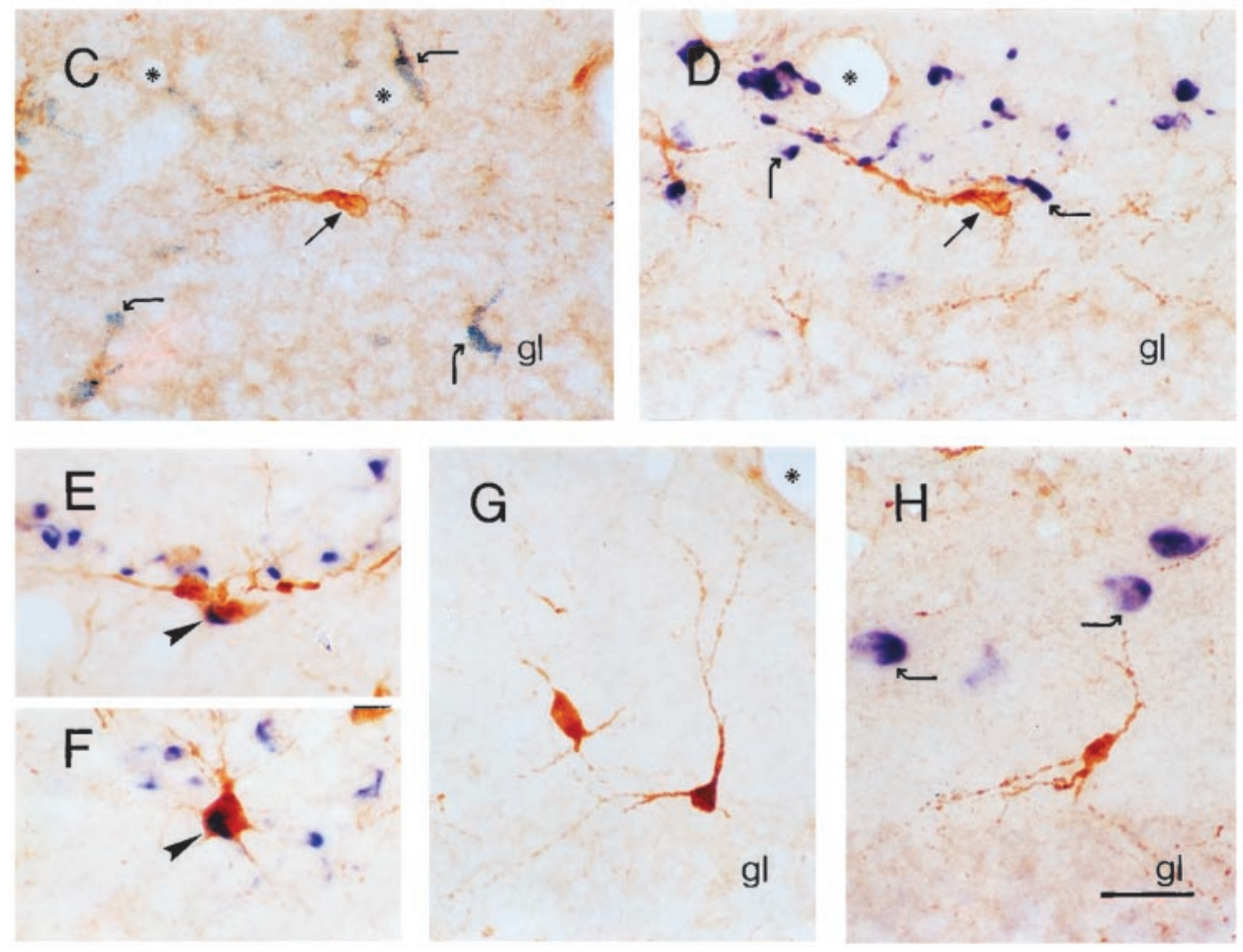

fects, and functional excitatory glutamatergic synaptic transmission is established (Ben-Ari et al., 1989; Hosokawa et al., 1994; Durand et al., 1996; Ben-Ari et al., 1997). This "switch" is accompanied by transient hyperexcitability of the hippocampal network (Gomez-Di Cesare et al., 1997). In these circumstances, alternative means of modulation of excitation and inhibition, provided by neuropeptides (e.g., CRH versus neuropeptide Y or somatostatin), might be advantageous. Once hippocampal maturation has been completed, this mechanism may become less important, resulting in neuropeptide downregulation. These may be reinduced in the adult by extreme neuronal activity (Gall et al., 1990; Schwarzer et al., 1996).

\section{The nature and fate of Cajal-Retzius cell-like CRH-IR neurons in developing hippocampus}

An unexpected result of our study was the discovery of a population of CRH-IR neurons in the developing hippocampus that, with respect to location, morphology, and neurochemical phenotype, was clearly distinguishable from the population of GABAergic CRH-IR interneurons. These neurons were located exclusively in slm of CA1 and $\mathrm{ml}$ of DG and were concentrated near the hippocampal fissure. Many of these cells had the characteristic morphology of Cajal-Retzius cells, and like them, did not express GAD67 mRNA. However, whereas many (D'Arcangelo et al.,
1995; Hirotsune et al., 1995; Ogawa et al., 1995) but not all Cajal-Retzius cells (Meyer et al., 1998) have been shown to express and secrete the glycoprotein reelin, CRH-immunoreactive CajalRetzius-like neurons did not coexpress reelin.

Cajal-Retzius cells have been shown to arise and die primarily within a defined developmental epoch (Soriano et al., 1994; Del Río et al., 1995; Drakew et al., 1998). Thus, Cajal-Retzius cells are the first neurons to differentiate in the developing cortex (Edmunds and Parnavelas, 1982; Marín-Padilla, 1984; Derer and Derer, 1990; Del Río et al., 1995; Meyer et al., 1998). They reside within the marginal zone of immature neocortex and disappear almost completely from this zone during its transformation to the cell-poor layer I, probably by degeneration (Derer and Derer, 1990). The hippocampal equivalents of the marginal zones (and neocortical layer I) are slm of hippocampus proper and the outer $\mathrm{ml}$ of DG. Both are densely populated by Cajal-Retzius cells during hippocampal formation, but, as in neocortex, most of these cells degenerate progressively with maturation (Del Río et al., 1995). The data presented here indicate that CRH-immunoreactive Cajal-Retzius cells demonstrate the same distinctive life profile.

The dates of birth and the fate of CRH-immunoreactive CajalRetzius cells support their designation as a distinct transient population of pioneer cells. Whereas the majority of GABAergic 



Figure 7. The Cajal-Retzius-like CRHexpressing population, born on E12, disappears at the same rate and time course of other (CRH-negative) Cajal-Retzius cell populations, likely via death. $A-C$, Cells born on E12 (labeled by BrdU injected on that day) are abundant in the hippocampal fissure (asterisks) of animals examined on P1 $(A)$ and $\mathrm{P} 5(B)$. A striking reduction in BrdU labeling is found by $\mathrm{P} 11(C) . D, E$, BrdU-labeled CRH-like Cajal-Retzius neurons (arrowheads) at $\mathrm{P} 1(D)$ and $\mathrm{P} 5(E) . F$, Left, Quantitative analysis of cells labeled with both $\mathrm{CRH}$ and BrdU compared with those labeled by BrdU alone suggests that these populations disappear at the same rate and time course. Numbers of BrdU singlelabeled cells are shown as black bars and are expressed per one section; numbers of CRH-BrdU double-labeled cells are shown as white bars and are expressed per eight sections. Right, The ratio of CRH-expressing Cajal-Retzius cells born on E12 to CajalRetzius-like CRH neurons [(CRH - BrdU)/ $\mathrm{CRH}]$ is similar in the three age groups, indicating that Cajal-Retzius-like CRH neurons labeled with $\mathrm{BrdU}$ are representative of the total population of CRH-expressing pioneer cells. Put together, these panels indicate that the fate of BrdU-CRH-labeled Cajal-Retzius cells and of the total CRH-expressing Cajal-Retzius cells conforms to the fate (death) of the general population of Cajal-Retzius cells in the hippocampal fissure. Scale bars: $A-C, 50 \mu \mathrm{m} ; D, E, 40 \mu \mathrm{m}$.

interneurons in the same regions are born at approximately E14 in the rat (Amaral and Kurz, 1985; Dupuy and Houser, 1997), CRH-immunoreactive Cajal-Retzius cells are likely born at approximately E12 (Fig. 7). A progressive disappearance of cells labeled by BrdU injection on E12 (born on that day) was evident (Fig. $7 F$ ), and the rate of disappearance of CRH-negative and CRH-expressing cells was similar. This is not consistent with a phenotypic change of CRH-immunoreactive Cajal-Retzius cells (which would have resulted in a steeper slope of disappearance of CRH-expressing cells, with a "transformation" of double-labeled into single BrdU-labeled cells) and indicates that, similar to other subpopulations (Del Río et al., 1995), CRH-immunoreactive Cajal-Retzius likely die.

\section{Potential function of CRH-expressing Cajal-Retzius cells}

Recent data indicate roles for hippocampal Cajal-Retzius cells in the pathfinding of entorhinal axons (Ceranik et al., 2000a) and as transient postsynaptic targets for these axons (Del Río et al., 1997). These actions of Cajal-Retzius cells may involve reelin, as evident from the severe cytoarchitectonic malformations in reelin-deficient (reeler) mice (for review, see Frotscher, 1998). However, our demonstration that a considerable proportion of hippocampal Cajal-Retzius cells does not express reelin indicates that this cell class is comprised of several subpopulations, with distinct neurochemical profiles and likely nonoverlapping functions (Ceranik et al., 2000b). Indeed, two temporally distinct populations of neocortical Cajal-Retzius cells, one reelinexpressing and the other reelin-negative, have been described recently (Meyer et al., 1998). The relationship of the CRHexpressing reelin-negative hippocampal Cajal-Retzius cell to these neocortical populations requires additional study.

What function could CRH-secreting Cajal-Retzius cells serve during hippocampal differentiation? $\mathrm{slm}$ and $\mathrm{ml}$ are innervated prenatally by ingrowing entorhinal cortex axons (Supèr and So- riano, 1994; Supèr et al., 1998). In the absence of their definitive postsynaptic targets (pyramidal and granule cell dendrites), these axons form transient synapses on Cajal-Retzius cells that provide guidance and synaptic targets (Del Río et al., 1997). However, at least certain subpopulations of cortical and hippocampal CajalRetzius cells have be shown recently to be physiologically active and to fire action potentials (Zhou and Hablitz, 1996; Aguiló et al., 1999, Mienville, 1999; Ceranik et al., 2000b). Indeed, their integration into the maturing network may trigger their death, because it is prevented by pharmacological blockade of NMDA receptors (Mienville and Pesold, 1999) or by elimination of entorhinal input (Del Río et al., 1996). Therefore, it was suggested recently (Mienville, 1999) that Cajal-Retzius cells may contribute to two critical aspects of circuit maturation: an early (perhaps reelin-dependent) (but see Ceranik et al., 2000b) phase of neuronal pathfinding and initial arborization, and a subsequent, activity-dependent phase promoting appropriate synaptogenesis. In this later, reelin-independent phase, the synaptic potentiation actions of CRH could play an important role.

In summary, the abundance of CRH-IR neurons in early postnatal hippocampus supports its potent physiological actions on developing hippocampal neurons and is consistent with important functions of the peptide during the "hyperexcitable" epoch of hippocampal maturation. In addition, the discovery of a novel, early and transient population of CRH-expressing Cajal-Retzius cells provides evidence for a much earlier contribution of $\mathrm{CRH}$ to processes underlying the progressive evolution of the hippocampus formation.

\section{REFERENCES}

Aguiló A, Schwartz TH, Kumar VS, Peterlin ZA, Tsiola A, Soriano E, Yuste R (1999) Involvement of Cajal-Retzius neurons in spontaneous correlated activity of embryonic and postnatal layer 1 from wild-type and reeler mice. J Neurosci 19:10856-10868.

Alcántara S, Ruiz M, D'Arcangelo G, Ezan F, de Lecea L, Curran T, Sotelo C, Soriano E (1998) Regional and cellular patterns of reelin 
mRNA expression in the forebrain of the developing and adult mouse. J Neurosci 18:7779-7799.

Aldenhoff JB, Gruol DL, Rivier J, Vale W, Siggins GR (1983) Corticotropin releasing factor decreases postburst hyperpolarizations and excites hippocampal neurons. Science 221:875-877.

Allen JM, McGregor GP, Woodhams PL, Polak JM, Bloom SR (1984) Ontogeny of a novel peptide, neuropeptide Y (NPY) in rat brain. Brain Res 303:197-200.

Amaral DG, Kurz J (1985) The time of origin of cells demonstrating glutamic acid decarboxylase-like immunoreactivity in the hippocampal formation of the rat. Neurosci Lett 59:33-39.

Avishai-Eliner S, Yi SJ, Baram TZ (1996) Developmental profile of messenger RNA for the corticotropin-releasing hormone receptor in the rat limbic system. Dev Brain Res 91:159-163.

Baram TZ, Hatalski CG (1998) Neuropeptide-mediated excitability: a key triggering mechanism for seizure generation in the developing brain. Trends Neurosci 21:471-476.

Baram TZ, Hirsch E, Snead III OC, Schultz L (1992) Corticotropinreleasing hormone-induced seizures in infant rats originate in the amygdala. Ann Neurol 31:488-494.

Baram TZ, Chalmers DT, Chen C, Koutsoukos Y, De Souza EB (1997) The $\mathrm{CRF}_{1}$ receptor mediates the excitatory actions of corticotropin releasing factor (CRF) in the developing rat brain: in vivo evidence using a novel, selective, non-peptide CRF receptor antagonist. Brain Res 770:89-95.

Ben-Ari Y, Cherubini E, Corradetti R, Gaiarsa JL (1989) Giant synaptic potentials in immature rat CA3 hippocampal neurones. J Physiol (Lond) 416:303-325.

Ben-Ari Y, Khazipov R, Leinekugel X, Caillard O, Gaiarsa JL (1997) GABAA, NMDA and AMPA receptors: a developmentally regulated "ménage à trois." Trends Neurosci 20:523-529.

Bender R, Hoffmann MC, Frotscher M, Nitsch C (2000) Species-specific expression of parvalbumin in the entorhinal cortex of the mongolian gerbil: dependence on local activity but not extrinsic afferents. Neuroscience 99:423-431.

Ceranik K, Deng J, Heimrich B, Lübke J, Zhao S, Förster E, Frotscher M (2000a) Hippocampal Cajal-Retzius cells project to the entorhinal cortex: retrograde tracing and intracellular labelling studies. Eur J Neurosci 11:4278-4290.

Ceranik K, Zhao S, Frotscher M (2000b) Development of the entorhino-hippocampal projection: guidance by Cajal-Retzius cell axons. Ann NY Acad Sci 911:43-54.

Chalmers DT, Lovenberg TW, De Souza EB (1995) Localization of novel corticotropin-releasing factor receptor $\left(\mathrm{CRF}_{2}\right)$ mRNA expression to specific subcortical nuclei in rat brain: comparison with $\mathrm{CRF}_{1}$ receptor mRNA expression. J Neurosci 15:6340-6350.

Chen Y, Brunson KL, Müller MB, Cariaga W, Baram TZ (2000) Immunocytochemical distribution of corticotropin-releasing hormone receptor type-1 (CRF(1))-like immunoreactivity in the mouse brain: light microscopy analysis using an antibody directed against the $\mathrm{C}$-terminus. J Comp Neurol 420:305-323.

Cho HJ, Shiotani Y, Shiosaka S, Inagaki S, Kubota Y, Kiyama H, Umegaki K, Tateishi K, Hashimura E, Hamaoka T, Tohyama M (1983) Ontogeny of cholecystokinin-8-containing neuron system of the rat: an immunohistochemical analysis. I. Forebrain and upper brainstem. J Comp Neurol 218:25-41.

Curtis AL, Pavcovich LA, Grigoriadis DE, Valentino RJ (1995) Previous stress alters corticotropin-releasing factor neurotransmission in the locus coeruleus. Neuroscience 65:541-550.

D’Arcangelo G, Miao GG, Chen SC, Soares HD, Morgan JI, Curran T (1995) A protein related to extracellular matrix proteins deleted in the mouse mutant reeler. Nature 374:719-723.

de Lecea L, Del Río JA, Criado JR, Alcántara S, Morales M, Danielson PE, Henriksen SJ, Soriano E, Sutcliffe JG (1997) Cortistatin is expressed in a distinct subset of cortical interneurons. J Neurosci 17:5868-5880.

Del Río JA, Martínez A, Fonseca M, Auladell C, Soriano E (1995) Glutamate-like immunoreactivity and fate of Cajal-Retzius cells in the murine cortex as identified with calretinin antibody. Cereb Cortex 5:13-21.

Del Río JA, Heimrich B, Supèr H, Borrell V, Frotscher M, Soriano E (1996) Differential survival of Cajal-Retzius cells in organotypic cultures of hippocampus and neocortex. J Neurosci 16:6896-6907.

Del Río JA, Heimrich B, Borrell V, Förster E, Drakew A, Alcántara S, Nakajima K, Miyata T, Ogawa M, Mikoshiba K, Derer P, Frotscher M, Soriano E (1997) A role for Cajal-Retzius cells and reelin in the development of hippocampal connections. Nature 385:70-74.

Derer P, Derer M (1990) Cajal-Retzius cell ontogenesis and death in mouse brain visualized with horseradish peroxidase and electron microscopy. Neuroscience 36:839-856.

Drakew A, Frotscher M, Deller T, Ogawa M, Heimrich B (1998) Developmental distribution of a reeler gene-related antigen in the rat hippocampal formation visualized by CR-50 immunocytochemistry. Neuroscience 82:1079-1086.

Dupuy ST, Houser CR (1997) Developmental changes in GABA neu- rons of the rat dentate gyrus: an in situ hybridization and birthdating study. J Comp Neurol 389:402-418.

Durand GM, Kovalchuk Y, Konnerth A (1996) Long-term potentiation and functional synapse induction in developing hippocampus. Nature 381:71-75.

Edmunds SM, Parnavelas JG (1982) Retzius-Cajal cells: an ultrastructural study in the developing visual cortex of the rat. J Neurocyto 11:427-446.

Ehlers CL, Henriksen SJ, Wang M, Rivier J, Vale W, Bloom FE (1983) Corticotropin releasing factor produces increases in brain excitability and convulsive seizures in rats. Brain Res 278:332-336.

Erlander MG, Tillakaratne NJ, Feldblum S, Patel N, Tobin AJ (1991) Two genes encode distinct glutamate decarboxylases. Neuron 7:91-100.

Fox EA, Gruol DL (1993) Corticotropin-releasing factor suppresses the afterhyperpolarization in cerebellar Purkinje neurons. Neurosci Lett 149:103-107.

Freund TF, Buzsáki G (1996) Interneurons of the hippocampus. Hippocampus 6:347-470.

Frotscher M (1998) Cajal-Retzius cells, Reelin, and the formation of layers. Curr Opin Neurobiol 8:570-575.

Gall C, Lauterborn J, Isackson P, White J (1990) Seizures, neuropeptide regulation, and mRNA expression in the hippocampus. Prog Brain Res 83:371-390.

Gomez-Di Cesare CM, Smith KL, Rice FL, Swann JW (1997) Axonal remodeling during postnatal maturation of CA3 hippocampal pyramidal neurons. J Comp Neurol 384:165-180.

Gray TS, Bingaman EW (1996) The amygdala: corticotropin-releasing factor, steroids, and stress. Crit Rev Neurobiol 10:155-168.

Gundersen HJ, Bagger P, Bendtsen TF, Evans SM, Korbo L, Marcussen N, M $\phi$ ller A, Nielsen K, Nyengaard JR, Pakkenberg B, Srensen FB Vesterby A, West MJ (1988) The new stereological tools: disector, fractionator, nucleator and point sampled intercepts and their use in pathological research and diagnosis. APMIS 96:857-881.

Haas CA, Deller T, Krsnik Z, Tielsch A, Woods A, Frotscher M (2000) Entorhinal cortex lesion does not alter reelin messenger RNA expression in the dentate gyrus of young and adult rats. Neuroscience 97:25-31.

Hatalski CG, Guirguis C, Baram TZ (1998) Corticotropin releasing factor mRNA expression in the hypothalamic paraventricular nucleus and the central nucleus of the amygdala is modulated by repeated acute stress in the immature rat. J Neuroendocrinol 10:663-669.

Hatalski CG, Brunson KL, Tantayanubutr B, Chen Y, Baram TZ (2000) Neuronal activity and stress differentially regulate hippocampal and hypothalamic corticotropin-releasing hormone expression in the immature rat. Neuroscience 101:571-580.

Hirotsune S, Takahara T, Sasaki N, Hirose K, Yoshiki A, Ohashi T, Kusakabe M, Murakami Y, Muramatsu M, Watanabe S, Nakao K, Katsuki M, Hayashizaki Y (1995) The reeler gene encodes a protein with an EGF-like motif expressed by pioneer neurons. Nat Genet 10:77-83.

Hollrigel GS, Chen K, Baram TZ, Soltesz I (1998) The pro-convulsant actions of corticotropin-releasing hormone in the hippocampus of infant rats. Neuroscience 84:71-79.

Holmes GL (1997) Epilepsy in the developing brain: lessons from the laboratory and clinic. Epilepsia 38:12-30.

Hosokawa Y, Sciancalepore M, Stratta F, Martina M, Cherubini E (1994) Developmental changes in spontaneous GABAA-mediated synaptic events in rat hippocampal CA3 neurons. Eur J Neurosci 6:805-813.

Houser CR, Esclapez M (1994) Localization of mRNAs encoding two forms of glutamic acid decarboxylase in the rat hippocampal formation. Hippocampus 4:530-545.

Jiang M, Swann JW (1997) Expression of calretinin in diverse neuronal populations during development of rat hippocampus. Neuroscience 81:1137-1154.

Kalin NH, Takahashi LK, Chen FL (1994) Restraint stress increases corticotropin-releasing hormone mRNA content in the amygdala and paraventricular nucleus. Brain Res 656:182-186.

Lee EH, Hung HC, Lu KT, Chen WH, Chen HY (1992) Protein synthesis in the hippocampus associated with memory facilitation by corticotropin-releasing factor in rats. Peptides 13:927-937.

Lee EH, Huang AM, Tsuei KS, Lee WY (1996) Enhanced hippocampal corticotropin-releasing factor gene expression associated with memory consolidation and memory storage in rats. Chin J Physiol 39:197-203.

Levey AI, Bolam JP, Rye DB, Hallanger AE, Demuth RM, Mesulam MM, Wainer BH (1986) A light and electron microscopic procedure for sequential double antigen localization using diaminobenzidine and benzidine dihydrochloride. J Histochem Cytochem 34:1449-1457.

Marín-Padilla M (1984) Neurons of layer I. A developmental analysis. In: Cerebral cortex, Vol I, Cellular components of the cerebral cortex (Peters A, Jones EG, eds), pp 447-478. New York: Plenum.

Merali Z, McIntosh J, Kent P, Michaud D, Anisman H (1998) Aversive and appetitive events evoke the release of corticotropin-releasing hormone and bombesin-like peptides at the central nucleus of the amygdala. J Neurosci 18:4758-4766.

Merchenthaler I (1984) Corticotropin releasing factor (CRF)-like immu- 
noreactivity in the rat central nervous system. Extrahypothalamic distribution. Peptides 5 [Suppl 1]:53-69.

Meyer G, Soria JM, Martínez-Galán JR, Martín-Clemente B, Fairén A (1998) Different origins and developmental histories of transient neurons in the marginal zone of the fetal and neonatal rat cortex. J Comp Neurol 397:493-518.

Mienville JM (1999) Cajal-Retzius cell physiology: just in time to bridge the 20th century. Cereb Cortex 9:776-782.

Mienville JM, Pesold C (1999) Low resting potential and postnatal upregulation of NMDA receptors may cause Cajal-Retzius cell death. J Neurosci 19:1636-1646.

Naus CCG, Morrison JH, Bloom FE (1988) Development of somatostatin-containing neurons and fibers in the rat hippocampus. Brain Res 468:113-121.

Ogawa M, Miyata T, Nakajima K, Yagyu K, Seike M, Ikenaka K, Yamamoto H, Mikoshiba K (1995) The reeler gene-associated antigen on Cajal-Retzius neurons is a crucial molecule for laminar organization of cortical neurons. Neuron 14:899-912.

Paxinos G, Watson C (1982) The rat brain in stereotaxic coordinates. New York: Academic.

Paxinos G, Tork I, Tecott LH, Valentino KL, Fritchle ALR (1991) Atlas of the developing rat brain. New York: Academic.

Pihoker C, Cain ST, Nemeroff CB (1992) Postnatal development of regional binding of corticotropin-releasing factor and adenylate cyclase activity in the rat brain. Prog Neuropsychopharmacol Biol Psychiatry 16:581-586.

Rainnie DG, Fernhout BJ, Shinnick-Gallagher P (1992) Differential actions of corticotropin releasing factor on basolateral and central amygdaloid neurones, in vitro. J Pharmacol Exp Ther 263:846-858.

Rivier J, Spiess J, Vale W (1983) Characterization of rat hypothalamic corticotropin-releasing factor. Proc Natl Acad Sci USA 80:4851-4855.

Sakanaka M, Shibasaki T, Lederis K (1987) Corticotropin releasing factor-like immunoreactivity in the rat brain as revealed by a modified cobalt-glucose oxidase-diaminobenzidine method. J Comp Neurol 260:256-298.

Schwarzer C, Sperk G, Samanin R, Rizzi M, Gariboldi M, Vezzani A (1996) Neuropeptides: immuno-reactivity and their mRNA expression in kindling: functional implications for limbic epileptogenesis. Brain Res Rev 22:27-50.

Smith BN, Dudek FE (1994) Age-related epileptogenic effects of corticotropin-releasing hormone in the isolated CA1 region of rat hippocampal slices. J Neurophysiol 72:2328-2333.

Smith MA, Weiss SR, Berry RL, Zhang LX, Clark M, Massenburg G, Post RM (1997) Amygdala-kindled seizures increase the expression of corticotropin-releasing factor (CRF) and CRF-binding protein in GABAergic interneurons of the dentate hilus. Brain Res 745:248-256.

Soltesz I, Smetters DK, Mody I (1995) Tonic inhibition originates from synapses close to the soma. Neuron 14:1273-1283.

Soriano E, Del Río JA, Martínez A, Supèr H (1994) Organization of the embryonic and early postnatal murine hippocampus. I. Immunocytochemical characterization of neuronal populations in the subplate and marginal zone. J Comp Neurol 342:571-595.

Sterio DC (1984) The unbiased estimation of number and sizes of arbitrary particles using the disector. J Microsc 134:127-136.

Supèr H, Soriano E (1994) The organization of the embryonic and early postnatal murine hippocampus. II. Development of entorhinal, commissural, and septal connections studied with the lipophilic tracer DiI. J Comp Neurol 344:101-120.

Supèr H, Martínez A, Del Río JA, Soriano E (1998) Involvement of distinct pioneer neurons in the formation of layer-specific connections in the hippocampus. J Neurosci 18:4616-4626.

Swann JW (1995) Synaptogenesis and epileptogenesis in developing neural networks. In: Brain development and epilepsy (Schwartzkroin PA, Moshe SL, Noebles JL, Swann JW, eds), pp 195-233. New York: Oxford UP.

Swanson LW, Sawchenko PE, Rivier J, Vale WW (1983) Organization of ovine corticotropin-releasing factor immunoreactive cells and fibers in the rat brain: an immunohistochemical study. Neuroendocrinology 36:165-186.

Swiergiel AH, Takahashi LK, Kalin NH (1993) Attenuation of stressinduced behavior by antagonism of corticotropin-releasing factor receptors in the central amygdala in the rat. Brain Res 623:229-234.

Takahashi T, Nowakowski RS, Caviness VS (1992) BUdR as an S-phase marker for quantitative studies of cytokinetic behavior in the murine cerebral ventricular zone. J Neurocytol 21:185-197.

Vale W, Spiess J, Rivier C, Rivier J (1981) Characterization of a 41 residue ovine hypothalamic peptide that stimulates secretion of corticotropin and beta-endorphin. Science 213:1394-1397.

Valentino RJ, Foote SL, Aston-Jones G (1983) Corticotropin-releasing factor activates noradrenergic neurons of the locus coeruleus. Brain Res 270:363-367.

Weiss GK, Castillo N, Fernandez M (1993) Amygdala kindling rate is altered in rats with a deficit in the responsiveness of the hypothalamopituitary-adrenal axis. Neurosci Lett 157:91-94.

West MJ (1999) Stereological methods for estimating the total number of neurons and synapses: issues of precision and bias. Trends Neurosci 22:51-61.

Yan XX, Toth Z, Schultz L, Ribak CE, Baram TZ (1998) Corticotropinreleasing hormone (CRH)-containing neurons in the immature rat hippocampal formation: light and electron microscopic features and colocalization with glutamate decarboxylase and parvalbumin. Hippocampus 8:231-243.

Yi SJ, Baram TZ (1994) Corticotropin-releasing hormone mediates the response to cold stress in the neonatal rat without compensatory enhancement of the peptide's gene expression. Endocrinology 135:2364-2368.

Zhou FM, Hablitz JJ (1996) Postnatal development of membrane properties of layer I neurons in rat neocortex. J Neurosci 16:1131-1139. 